Brit. J. vener. Dis. (1959), 35, 223.

\title{
TREATMENT OF NON-GONOCOCCAL URETHRITIS WITH SIGMAMYCIN*
}

\section{A CONTROLLED METHOD OF INVESTIGATION}

\author{
BY \\ W. LEACH \\ Department of Venereal Diseases, St. Thomas's Hospital, London
}

Many different drugs have been tried for treating non-gonococcal urethritis (NGU) with varying degrees of success; this report describes an attempt to evaluate the effect of Sigmamycin at two different dosage levels.

Sigmamycin is a $2: 1$ combination of the antibiotics tetracycline hydrochloride and oleandomycin phosphate, and the claim has been made that this combination exhibits a synergistic action, so that the two drugs together are more potent than the sum of the individual components. To test this claim two separate trial series of patients were treated, using a small dose for a minimum time in the first, and a large dose for a slightly longer period in the second. In each series controls were used and the drug or a placebo was administered by the double-blind method to a total of 200 white male patients with non-gonococcal urethritis. Neither patients nor medical staff knew who received antibiotic or placebo, and the key to the coding used was retained by the suppliers of the drug until the completion of each half of the trial.

A certain amount of selection of patients was used, those giving a history of gonorrhoea or NGU within a year, those who had recently had treatment, and those who were unlikely to attend for follow up being excluded from the trial.

\footnotetext{
* Received for publication May 25, 1959.
}

\section{Method}

The patients were first seen in the ordinary clinic, the history was taken, a full examination was carried out and the preliminary diagnosis of non-gonococcal urethritis was confirmed by examination of an urethral smear. Cultures were set up to exclude gonorrhoea and to reveal any bacteria present in the discharge. In addition, a fresh wet preparation and culture were examined routinely for Trichomonas vaginalis. Finally, the result of the two-glass test was carefully recorded and blood was taken for serological tests for syphilis. Patients were seen again the following morning whenever possible, for an early morning test (E.M.S.) before urinating. This included urethral scraping of the terminal urethra and fossa navicularis, and a further search for $T$. vaginalis in a wet preparation and by culture. The two-glass test was then carried out and recorded. Anyone who on first attending had held his urine overnight or for 8 hours or more was excused attending for an E.M.S. the next morning.

Contact slips were issued, and each patient was exhorted to send along his recent sex contacts. Finally, each patient was handed a bottle containing the capsules, taken at random from the cupboard and bearing only a label with a number on it and instructions how to take the drug. Alcohol and sexual intercourse were banned during the period of attendance at the clinic.

In order to standardize the follow-up tests, the first hundred patients were asked to attend in the early morning before urinating. In this way a two-glass test could be carried out as a standard procedure on the first urine specimen of the day, and a truer indication could be obtained of the response to treatment. As far as possible. 
one examiner only recorded the test results. This procedure was modified for the second hundred when it was discovered that many patients, on close questioning, had not in fact been able to hold their urine, so invalidating the test. Also, the quantity of the first spezimen could vary between a few $\mathrm{ml}$. and a full glass, whatever directive was issued. Accordingly, each of the second batch of patients was issued with a sterile $2-0 z$. bottle for the first specimen and was told to conduct the two-glass test himself on rising on the day of attendance at the clinic, using a convenient large bottle for the second specimen.

At the end of the fourth or fifth week, prostatic massage was carried out if signs of urethritis had abated. Wet preparations of the prostatic secretion were examined for pus calls and the $T$. vaginalis, and a stained preparation was read later. Those patients who had developed chronic prostatitis were treated appropriately.

Re-treatment with known drugs had to be resorted to when there was no response over a period of several weeks, or when complications (e.g. cystitis) supervened. The number of weeks elapsing before re-treatment in the "no-response" cases varied according to the type of patient. Ideally, they were left for 8 weeks without specific treatment and placebos such as vitamins and Mist. pot. cit. were administered. This period was chosen because Gartman and Leibovitz (1955) claimed that there was a spontaneous cure without treatment in $58 \cdot 5$ per cent. of cases within 8 weeks. However, some more anxious patients had to be re-treated earlier than the eighth week if their condition did not seem to be improving. Those who had recurrences were treated appropriately, according to the severity of the recurrence, and the cause was noted.

Each patient was seen weekly until a fortnight after their two specimens of urine were quite clear, fortnightly for 8 weeks, and at the end of 12 weeks.

\section{Results}

The information collected during the trial in respect of history, aetiology, symptoms, signs, and subjective and objective response to therapy was later transferred to punch cards (Fig. 1).

The dose used in the first hundred patients was $100 \mathrm{mg}$. Sigmamycin 6-hrly for 4 days, and for the second hundred, $500 \mathrm{mg}$. Sigmamycin 6-hrly for 5 days. The placebo used was lactose in each series. A subjective response was indicated by the patient's own observations of when his symptoms decreased and finally disappeared, and thus was recorded separately from the clinical findings. The objective

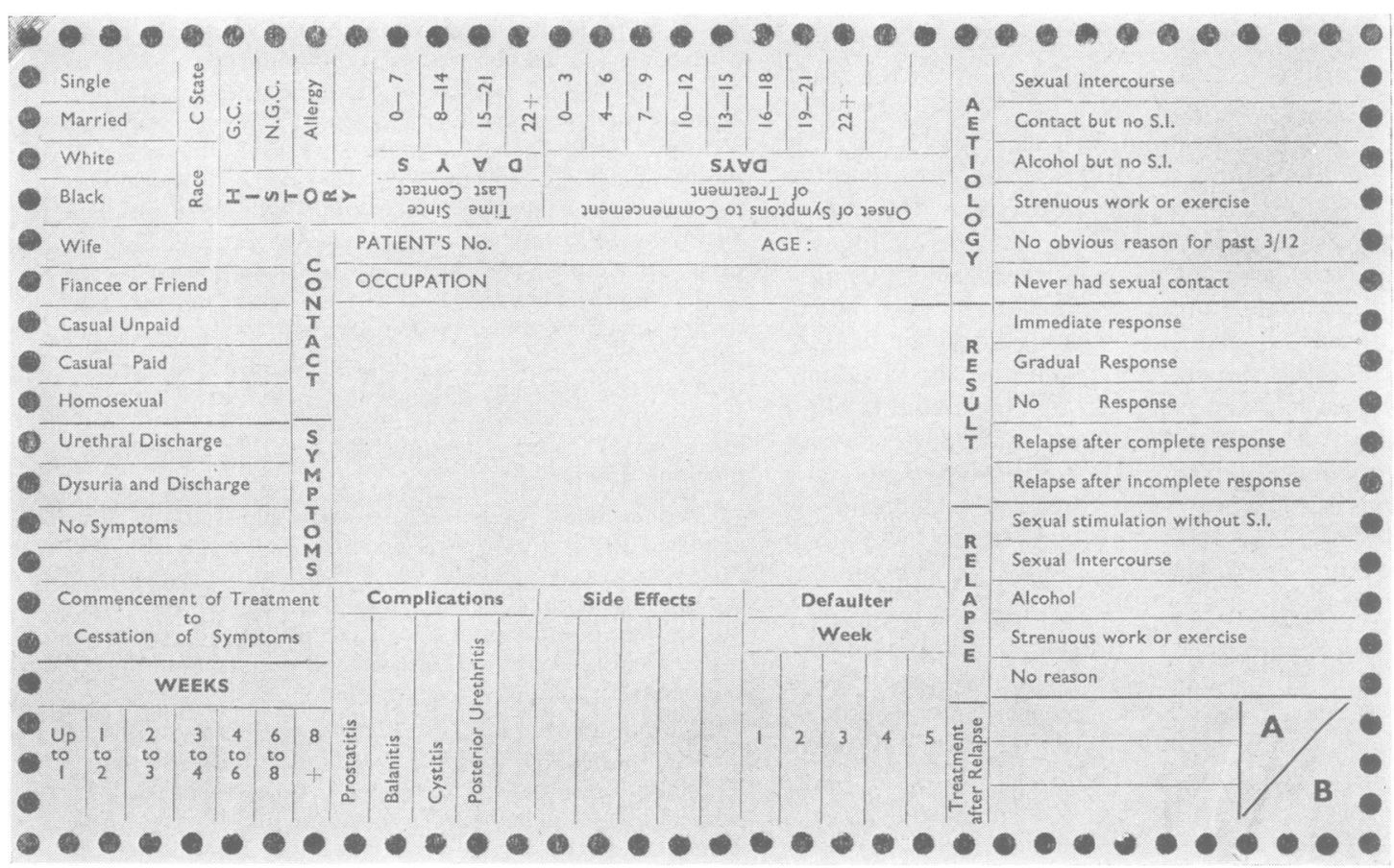

FIG. 1.-Punch card for recording particulars of each patient. 
response was a more scientific record of the weekly two-glass test on the E.M.S. A precise grading of the findings in the two-glass test was used, beginning with the normal and becoming progressively more severe through ten grades (Figs 2-6).

The first two grades were regarded as within normal limits. If the eighth grade (Haze/Haze) or more was noted - this usually indicated an ascending renal tract infection and the need for further treatment. For the purpose of classifying the response to treatment, the appearance of the graph decided into which of four categories the particular case was to be placed. Thus, those whose two-glass test was normal within about
7 days of taking the capsules were said to show an immediate response (Fig. 2). Those whose specimens took longer to clear than 2 weeks from starting treatment, fell into the gradual response category (Fig. 3). A gradual response might take up to 8 weeks. Any whose specimens showed little or no improvement for 8 weeks were said to show no response, as did also those whose condition worsened after taking the capsules, and who therefore had to be re-treated with other drugs (Fig. 4). The fourth category included any who had recurrences during resolution (i.e. gradual response) or following cure (i.e. immediate response) (Figs 5 and 6). The cause, if any, of the recurrence was noted.

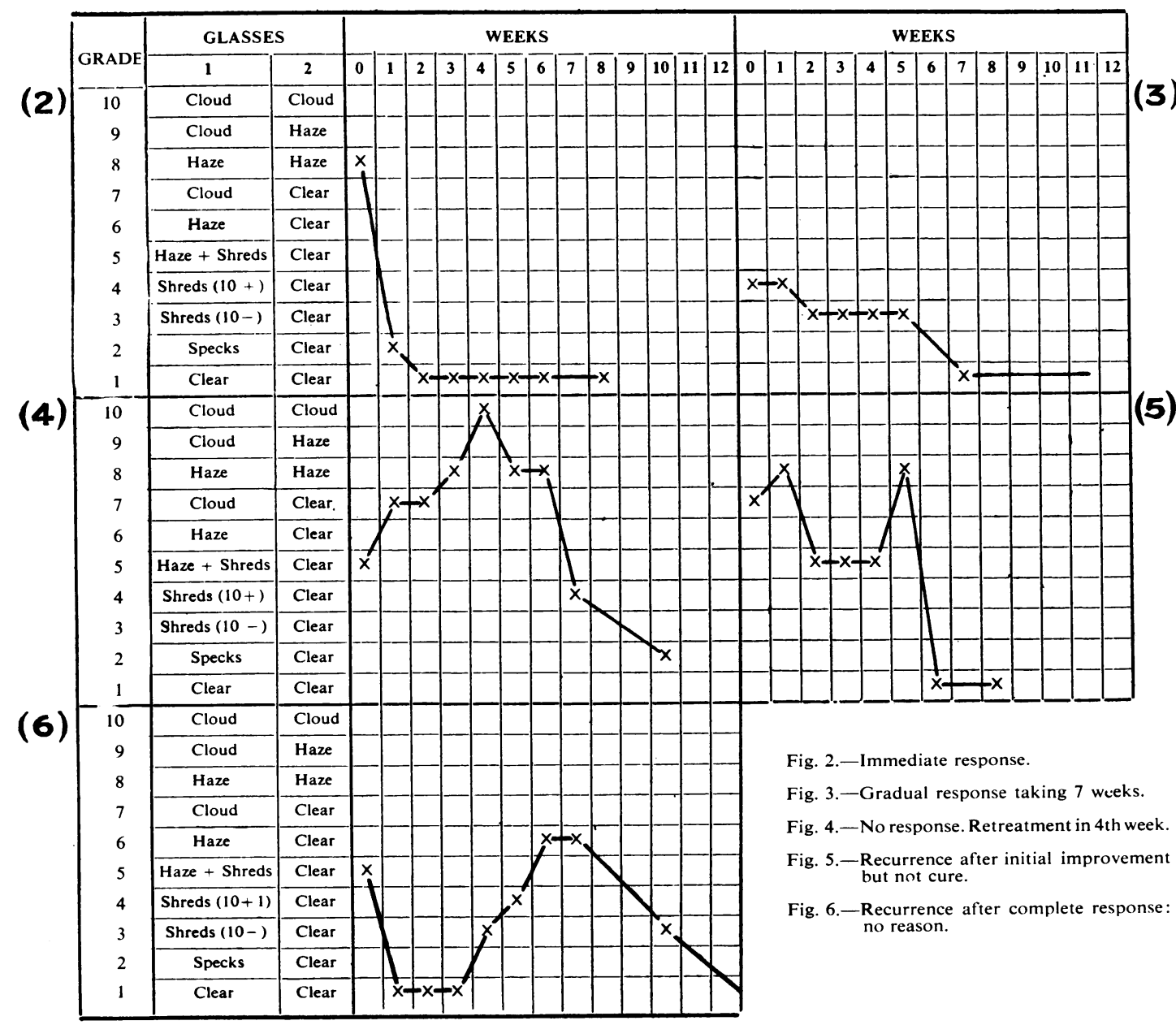


After the completion of each half of the trial, the results were analysed and a series of tables was prepared, in which the patients are classified into four groups:

$A_{1}$ Those treated with the small dose of Sigmamycin;

$A_{2}$ Those treated with the larger dose of Sigmamycin;

$B_{1}$ Controls to Group $A_{1}$;

$B_{2}$ Controls to Group $A_{2}$.

Men contracting NGU were most commonly in their twenties or thirties; Table I also shows that the Controls $B_{1}$ and $B_{2}$ were a representative group with respect to age incidence.

TABLE I

AGE INCIDENCE

\begin{tabular}{l|c|c|c|c|c|c}
\hline \multicolumn{1}{l|}{ Age (yrs) } &. & -20 & $21-30$ & $31-40$ & $41-50$ & $50+$ \\
\hline & $\mathbf{A}_{1}$ & 4 & 20 & 19 & 5 & 1 \\
Group .. & $\mathbf{A}_{2}$ & 3 & 19 & 15 & 10 & 3 \\
\cline { 2 - 6 } & $\mathbf{B}_{1}$ & 4 & 24 & 11 & 8 & 3 \\
& $\mathbf{B}_{2}$ & 3 & 23 & 10 & 9 & 4 \\
\hline Totals.. &.. & 14 & 86 & 55 & 32 & 11 \\
\hline $\begin{array}{c}\text { Percentage } \\
\text { Incidence }\end{array}$ &.. & 7 & 43 & $27 \cdot 5$ & 16 & $5 \cdot 5$ \\
\hline
\end{tabular}

Single men outnumbered married men except in the second group of controls (Table II). However, the total incidence shows that single men do not significantly outnumber married men contracting NGU.

TABLE II

MARITAL STATUS

\begin{tabular}{|c|c|c|c|c|c|}
\hline Status . . & . & $\cdots$ & . & Married & Single \\
\hline \multirow{2}{*}{ Group } & \multirow{2}{*}{. } & & $\begin{array}{l}\mathbf{A}_{1} \\
\mathbf{A}_{2}\end{array}$ & $\begin{array}{l}20 \\
23\end{array}$ & $\begin{array}{l}30 \\
27\end{array}$ \\
\hline & & & $\begin{array}{l}\mathbf{B}_{1} \\
\mathbf{B}_{2}\end{array}$ & $\begin{array}{l}17 \\
33\end{array}$ & $\begin{array}{l}33 \\
17\end{array}$ \\
\hline Totals.. & . & . & $\cdots$ & 93 & 107 \\
\hline \multicolumn{3}{|c|}{ Percentage Incidence } & $\ldots$ & $46 \cdot 5$ & $53 \cdot 5$ \\
\hline
\end{tabular}

The chief symptom was urethral discharge in 93.5 per cent., and about half of these patients also (48 per cent.) complained of dysuria. A few patients who came for routine "check up" without any symptoms were found to have NGU. Again, there was an even distribution throughout controls and treated cases (Table III).

TABLE III

SYMPTOMS

\begin{tabular}{|c|c|c|c|c|c|}
\hline Symptoms & .. & $\begin{array}{l}\text { Urethral } \\
\text { Discharge }\end{array}$ & $\begin{array}{l}\text { Urethral } \\
\text { Discharge } \\
+ \text { Dysuria }\end{array}$ & Dysuria & $\begin{array}{c}\text { No } \\
\text { Symptoms }\end{array}$ \\
\hline \multirow{2}{*}{ Group.. } & $\begin{array}{l}\mathbf{A}_{1} \\
\mathbf{A}_{2}\end{array}$ & $\begin{array}{l}23 \\
25\end{array}$ & $\begin{array}{l}27 \\
20\end{array}$ & $\begin{array}{l}0 \\
5\end{array}$ & $\begin{array}{l}0 \\
0\end{array}$ \\
\hline & $\begin{array}{l}\mathbf{B}_{1} \\
\mathbf{B}_{2}\end{array}$ & $\begin{array}{l}23 \\
20\end{array}$ & $\begin{array}{l}24 \\
25\end{array}$ & $\begin{array}{l}0 \\
2\end{array}$ & $\begin{array}{l}3 \\
3\end{array}$ \\
\hline \multicolumn{2}{|l|}{ Totals } & 91 & 96 & 7 & 6 \\
\hline Percentage & . & $45 \cdot 5$ & 48 & $3 \cdot 5$ & 3 \\
\hline \multicolumn{2}{|c|}{$\begin{array}{c}\text { Total with Urethral } \\
\text { Discharge }\end{array}$} & \multicolumn{4}{|c|}{$45 \cdot 5+48=93 \cdot 5$ per cent. } \\
\hline
\end{tabular}

Table IV shows that 42 per cent. of the patients reported within 3 days of the onset of symptoms, and 68.5 per cent. within the first 6 days. Some, however, had had symptoms for more than 3 weeks, and one had had symptoms for more than a year.

Table VA (opposite) shows that, except in Group $A_{1}$, the contact was most commonly a regular girl friend or fiancée, or, less often, a casual, unpaid pick-up.

Table Vв (opposite) shows that non-gonococcal cervicitis was the most usual finding in those contacts who attended. Unfortunately, three-quarters of the total number of contacts failed to attend.

"Incubation Period".-This was assumed to be the time elapsing between the patient's last sex contact and the onset of symptoms. Patients had mostly had sex contact within 7 days, but many had not had contact for weeks (Table VI, opposite). The averages for the different groups are closely similar and the total average works out at $11 \cdot 7$ days.

TABLE IV

DURATION OF SYMPTOMS

\begin{tabular}{|c|c|c|c|c|c|c|c|c|c|c|c|}
\hline Duratior & (days) .. & .. & $0-3$ & 4-6 & 7-9 & $10-12$ & $13-15$ & $16-18$ & $19-21$ & $22+$ & $365+$ \\
\hline \multirow{2}{*}{ Group } & & $\begin{array}{l}\mathbf{A}_{1} \\
\mathbf{A}_{2}\end{array}$ & $\begin{array}{l}15 \\
26\end{array}$ & $\begin{array}{l}13 \\
14\end{array}$ & $\begin{array}{l}8 \\
4\end{array}$ & $\begin{array}{l}\mathbf{6} \\
2\end{array}$ & $\begin{array}{l}1 \\
3\end{array}$ & $\begin{array}{l}1 \\
0\end{array}$ & $\begin{array}{l}\mathbf{0} \\
\mathbf{0}\end{array}$ & $\begin{array}{l}6 \\
1\end{array}$ & $\begin{array}{l}\mathbf{0} \\
\mathbf{0}\end{array}$ \\
\hline & & $\begin{array}{l}\mathbf{B}_{1} \\
\mathbf{B}_{\mathbf{2}} \\
\end{array}$ & $\begin{array}{l}14 \\
29\end{array}$ & $\begin{array}{l}14 \\
12 \\
\end{array}$ & $\begin{array}{r}10 \\
3 \\
\end{array}$ & $\begin{array}{l}3 \\
\mathbf{0} \\
\end{array}$ & $\begin{array}{l}4 \\
2 \\
\end{array}$ & $\begin{array}{l}1 \\
0\end{array}$ & $\begin{array}{l}1 \\
3 \\
\end{array}$ & $\begin{array}{l}3 \\
0 \\
\end{array}$ & $\begin{array}{l}0 \\
1\end{array}$ \\
\hline Totals & $\ldots$ & $\ldots$ & 84 & 53 & 25 & 11 & 10 & 2 & 4 & 10 & 1 \\
\hline \multicolumn{3}{|c|}{ Total Percentage First 6 Days .. } & \multicolumn{9}{|c|}{$42+26 \cdot 5=68 \cdot 5$ per cent. } \\
\hline
\end{tabular}


TABLE VA

CONTACTS

\begin{tabular}{|c|c|c|c|c|c|c|}
\hline \multirow{2}{*}{ Contact } & \multirow{2}{*}{. } & \multirow{2}{*}{$\begin{array}{c}\text { Fiancée } \\
\text { or } \\
\text { Friend }\end{array}$} & \multicolumn{2}{|c|}{ Casual } & \multirow{2}{*}{ Wife } & \multirow{2}{*}{$\begin{array}{l}\text { Homo- } \\
\text { sexual }\end{array}$} \\
\hline & & & Unpaid & Paid & & \\
\hline \multirow{2}{*}{ Group } & $\begin{array}{l}\mathbf{A}_{1} \\
\mathbf{A}_{2}\end{array}$ & $\begin{array}{l}12 \\
18\end{array}$ & $\begin{array}{l}18 \\
12\end{array}$ & $\begin{array}{r}12 \\
9\end{array}$ & $\begin{array}{r}8 \\
11\end{array}$ & $\begin{array}{l}0 \\
0\end{array}$ \\
\hline & $\begin{array}{l}\mathbf{B}_{1} \\
\mathbf{B}_{2}\end{array}$ & $\begin{array}{l}23 \\
18\end{array}$ & $\begin{array}{l}14 \\
16\end{array}$ & $\begin{array}{r}6 \\
12\end{array}$ & $\begin{array}{l}7 \\
4\end{array}$ & $\begin{array}{l}0 \\
0\end{array}$ \\
\hline Total & . & 71 & 60 & 39 & 30 & 0 \\
\hline Percentage & . & $35 \cdot 5$ & 30 & $19 \cdot 5$ & 15 & 0 \\
\hline
\end{tabular}

TABLE VB

DISEASE IN CONTACTS

\begin{tabular}{l|c|c|c|c|c}
\hline Disease .. & $\ldots$ & $\begin{array}{c}\text { Non- } \\
\text { Gonococcal } \\
\text { Cervicitis }\end{array}$ & $\begin{array}{c}T . \\
\text { Vaginalis }\end{array}$ & $\begin{array}{c}\text { No Ab- } \\
\text { normality }\end{array}$ & $\begin{array}{c}\text { Contact } \\
\text { Not } \\
\text { Traced }\end{array}$ \\
\hline Group .. & $\mathrm{A}_{1}$ & 8 & 2 & 0 & 40 \\
& $\mathbf{A}_{2}$ & 14 & 1 & 1 & 34 \\
\hline $\mathbf{B}_{1}$ & 11 & 1 & 0 & 38 \\
\hline Totals ... & $\ldots$ & 7 & 3 & 1 & 39 \\
\hline Percentage & $\ldots$ & 40 & 7 & 2 & 151 \\
\hline
\end{tabular}

38 per cent. gave a past history of urethritis (Table VII), the proportion of non-gonococcal to gonococcal infections being about equal.

The subjective response to treatment indicated by the patient's reply to the question, "Has your discharge ceased?" is shown in Table VIIIA; roughly the same number (29 and 28 ) in the two treated groups $A_{1}$ and $A_{2}$ were better within a week, whereas only seventeen and nine, respectively, of the two control groups were better.
TABLE VI

TIME SINCE LAST CONTACT

\begin{tabular}{|c|c|c|c|c|c|c|}
\hline Time (days) & .. & $0-7$ & $8-14$ & $15-21$ & $22+$ & $\begin{array}{l}\text { Average No. } \\
\text { Days Since } \\
\text { Last Contact }\end{array}$ \\
\hline \multirow{2}{*}{ Group } & $\begin{array}{l}\mathbf{A}_{1} \\
\mathbf{A}_{2}\end{array}$ & $\begin{array}{l}23 \\
21\end{array}$ & $\begin{array}{l}13 \\
12\end{array}$ & $\begin{array}{l}7 \\
7\end{array}$ & $\begin{array}{r}7 \\
10\end{array}$ & $\begin{array}{l}10 \cdot 7 \\
11 \cdot 8\end{array}$ \\
\hline & $\begin{array}{l}\mathbf{B}_{1} \\
\mathbf{B}_{2}\end{array}$ & $\begin{array}{l}23 \\
16\end{array}$ & $\begin{array}{r}9 \\
16\end{array}$ & $\begin{array}{l}9 \\
8\end{array}$ & $\begin{array}{r}9 \\
10\end{array}$ & $\begin{array}{l}11 \cdot 6 \\
12 \cdot 7\end{array}$ \\
\hline \multicolumn{2}{|l|}{ Totals $\quad}$. & 83 & 50 & 31 & 36 & $46 \cdot 8$ \\
\hline Percentage & . & $41 \cdot 5$ & 25 & $15 \cdot 5$ & 18 & Average $=11.7$ \\
\hline
\end{tabular}

TABLE VII

PATIENT'S PREVIOUS HISTORY OF URETHRITIS

\begin{tabular}{|c|c|c|c|c|}
\hline History. . & .. & Gonorrhoea & $\begin{array}{l}\text { Non- } \\
\text { Gonococcal } \\
\text { Urethritis }\end{array}$ & No History \\
\hline \multirow{2}{*}{ Group. . } & $\begin{array}{l}\mathbf{A}_{1} \\
\mathbf{A}_{2}\end{array}$ & $\begin{array}{r}7 \\
11\end{array}$ & $\begin{array}{l}6 \\
7\end{array}$ & $\begin{array}{l}37 \\
32\end{array}$ \\
\hline & $\begin{array}{l}\mathbf{B}_{1} \\
\mathbf{B}_{2}\end{array}$ & $\begin{array}{r}6 \\
14\end{array}$ & $\begin{array}{l}12 \\
13\end{array}$ & $\begin{array}{l}32 \\
23\end{array}$ \\
\hline Totals & $\ldots$ & 38 & 38 & 124 \\
\hline Percentage & . & 19 & 19 & 62 \\
\hline
\end{tabular}

The most interesting figures are seen in the Tables showing the true response to treatment as measured by the two-glass test.

Table VIIIB shows the numbers in each of the categories mentioned previously, and in addition the total number followed-up for a sufficient period to be able to reach a conclusion.

It is evident that, in the first series, thirteen of the treated patients and ten of the controls claimed that their discharge had ceased after one week, when, in

TABLE VIIIA

SUBJECTIVE RESPONSE TO TREATMENT

\begin{tabular}{|c|c|c|c|c|c|c|c|c|c|c|c|}
\hline \multicolumn{3}{|c|}{${ }_{\text {Duration of Follow-up }}$} & \multirow{2}{*}{$\begin{array}{c}\text { Up to } 1 \\
\begin{array}{r}29 \\
17\end{array}\end{array}$} & \multirow{2}{*}{$\begin{array}{r}1-2 \\
7 \\
10\end{array}$} & \multirow{2}{*}{$\frac{2-3}{2}$} & \multirow{2}{*}{$\begin{array}{r}3-4 \\
4 \\
6\end{array}$} & \multirow{2}{*}{$\begin{array}{r}4-6 \\
0 \\
5\end{array}$} & \multirow{2}{*}{$\begin{array}{r}6-8 \\
2 \\
3\end{array}$} & \multirow{2}{*}{$\begin{array}{r}8+ \\
1 \\
0\end{array}$} & \multirow{2}{*}{$\begin{array}{c}\begin{array}{c}\text { No } \\
\text { Record }\end{array} \\
5 \\
7 \\
\end{array}$} & \multirow{2}{*}{\begin{tabular}{|c|c}
$\begin{array}{c}\text { No. of Patients } \\
\text { Followed-up }\end{array}$ \\
45 \\
43 \\
\end{tabular}} \\
\hline Srou & & $\begin{array}{l}\mathbf{A}_{1} \\
\mathbf{B}_{1}\end{array}$ & & & & & & & & & \\
\hline 年 & $\cdots$ & $\begin{array}{l}\mathbf{A}_{2} \\
\mathbf{B}_{2}\end{array}$ & $\begin{array}{r}28 \\
9\end{array}$ & $\begin{array}{l}7 \\
9\end{array}$ & 2 & $\begin{array}{l}2 \\
8\end{array}$ & $\begin{array}{l}\mathbf{0} \\
2\end{array}$ & $\begin{array}{l}0 \\
1\end{array}$ & $\frac{1}{3}$ & $\begin{array}{l}10 \\
16\end{array}$ & $\begin{array}{l}40 \\
34\end{array}$ \\
\hline
\end{tabular}

TABLE VIIIB

RESPONSE ACCORDING TO TESTS

\begin{tabular}{|c|c|c|c|c|c|c|c|c|c|}
\hline \multirow{2}{*}{\multicolumn{2}{|c|}{ Response }} & \multirow[b]{2}{*}{.. } & \multirow[b]{2}{*}{ Immediate } & \multirow[b]{2}{*}{ Gradual } & \multirow[b]{2}{*}{ None } & \multirow[b]{2}{*}{ No Record } & \multirow{2}{*}{$\begin{array}{l}\text { No. of Patients } \\
\text { Followed-up }\end{array}$} & \multicolumn{2}{|c|}{ Recurrence } \\
\hline & & & & & & & & After Cure & $\begin{array}{c}\text { During } \\
\text { Resolution }\end{array}$ \\
\hline \multirow{2}{*}{ Group } & \multirow{2}{*}{.. } & $\begin{array}{l}\mathbf{A}_{1} \\
\mathbf{B}_{1}\end{array}$ & $\begin{array}{r}16 \\
7\end{array}$ & $\begin{array}{l}18 \\
16\end{array}$ & $\begin{array}{r}7 \\
15\end{array}$ & $\begin{array}{r}9 \\
12\end{array}$ & $\begin{array}{l}41 \\
38\end{array}$ & $\begin{array}{l}9 \\
0\end{array}$ & 4 \\
\hline & & $\begin{array}{l}\mathbf{A}_{2} \\
\mathbf{B}_{2}\end{array}$ & $\begin{array}{l}32 \\
11\end{array}$ & $\begin{array}{l}10 \\
16\end{array}$ & $\begin{array}{r}3 \\
17\end{array}$ & $\begin{array}{l}5 \\
6\end{array}$ & $\begin{array}{l}45 \\
44\end{array}$ & $\begin{array}{l}7 \\
2\end{array}$ & $\begin{array}{l}2 \\
1\end{array}$ \\
\hline
\end{tabular}


TABLE VIIIC

RESPONSE RATE:

PERCENTAGES OF NO. FOLLOWED UP

\begin{tabular}{|c|c|c|c|c|c|c|c|c|}
\hline \multirow{2}{*}{\multicolumn{2}{|c|}{ Response (per cent.) .. }} & \multirow{3}{*}{$\begin{array}{c}\text { Immediate } \\
39 \\
18\end{array}$} & \multirow{3}{*}{$\begin{array}{c}\text { Gradual } \\
44 \\
42\end{array}$} & \multirow{3}{*}{$\begin{array}{c}\text { None } \\
17 \\
40\end{array}$} & \multirow{3}{*}{$\begin{array}{c}\text { No Record } \\
9 \\
12\end{array}$} & \multirow{3}{*}{$\begin{array}{c}\begin{array}{c}\text { No. of Patients } \\
\text { Followed-up }\end{array} \\
41 \\
38 \\
\end{array}$} & \multicolumn{2}{|c|}{ Recurrence (per cent.) } \\
\hline & & & & & & & \multirow{2}{*}{ 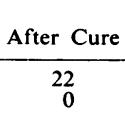 } & \multirow{2}{*}{$\begin{array}{c}\begin{array}{c}\text { During } \\
\text { Resolution }\end{array} \\
\begin{array}{r}2 \cdot 5 \\
10 \cdot 5\end{array}\end{array}$} \\
\hline \multirow{2}{*}{ Group } & $\begin{array}{l}\mathbf{A}_{1} \\
\mathbf{B}_{1}\end{array}$ & & & & & & & \\
\hline & $\begin{array}{l}\mathbf{A}_{2} \\
\mathbf{B}_{2}\end{array}$ & $\begin{array}{l}71 \\
25\end{array}$ & $\begin{array}{l}22 \\
36\end{array}$ & $\begin{array}{r}7 \\
39\end{array}$ & $\begin{array}{l}5 \\
6\end{array}$ & $\begin{array}{l}45 \\
44\end{array}$ & $\begin{array}{r}15 \cdot 5 \\
4 \cdot 5\end{array}$ & ${ }_{2}^{4 \cdot 5}$ \\
\hline
\end{tabular}

fact, early morning tests proved that pyuria was still present. Oates (1958) pointed out this discrepancy as a possible misleading factor in assessing results of treatment. When a larger dose was used, as in the second series (28 treated and nine controls), the subjective response was a much truer indication of whether resolution had occurred, since in all cases pyuria was absent after one week.

When these results are worked out as percentages (Table VIIIC), it is seen that a small dose of Sigmamycin produces an immediate response in 39 per cent., but that 18 per cent. (controls) would show an immediate response without any treatment at all. Thus, a small dose of Sigmamycin produces an immediate response in only 21 per cent. more cases than would respond immediately without treatment. Taking the gradual response category, roughly the same percentage ( 44 per cent. as opposed to 42 per cent.) will resolve in a matter of 8 weeks whether treated or not. This leaves 17 per cent. of the treated cases not responding to Sigmamycin as opposed to 40 per cent. of the controls still with urethritis after 8 weeks.

In the second series, a larger dose of Sigmamycin produces an immediate response in 71 per cent. of cases, whereas 25 per cent (controls) would get better quickly anyway, an improvement of 46 per cent. This improvement factor is thus much greater than that seen when using a smaller dose. In the gradual response group, a further 22 per cent. responded within 8 weeks on Sigmamycin and 36 per cent. responded in spite of receiving no specific treatment, leaving only 7 per cent. who failed to respond to Sigmamycin as opposed to 39 per cent. of the controls who still had urethritis after 8 weeks.

Of those who had recurrences, the Table shows that the majority ( 22 per cent. and $15 \cdot 5$ per cent. of those followed up in Groups 1 and 2 respectively) occurred after complete cure rather than during a gradual response, which is what one might expect for the treated group. There seemed to be fewer recurrences altogether in the control groups, presumably because fewer were cured. A recurrence following complete "cure" seemed slightly less likely if the larger dose of Sigmamycin was used.

If Table VIIlв is now considered, it is very interesting to discover that, taking the whole 8-week period used for measuring the response, i.e. those responding gradually added to those responding immediately, the successes were 83 per cent. of cases treated with a small dose and 93 per cent. of the cases treated with a larger dose, and that the two control groups came out remarkably close together (around the 60 per cent. level). This indicates that this proportion, less recurrences, would be symptom-free without any treatment at the end of 8 weeks. The improvement factor is thus about 23 per cent. in the small dose series over an 8-week period, and 32 per cent. for the larger dose series, a significant difference. There seems to be slightly more likelihood of a recurrenceo at some stage during the 8 weeks following a small dose of the drug than after the use of a larger dose. The average recurrence rate for the two control groups is 8.5 per cent. (Table VIIID).

TABLE VIIID

PERCENTAGE SUCCESSES AT THE END OF EIGHT WEEKS

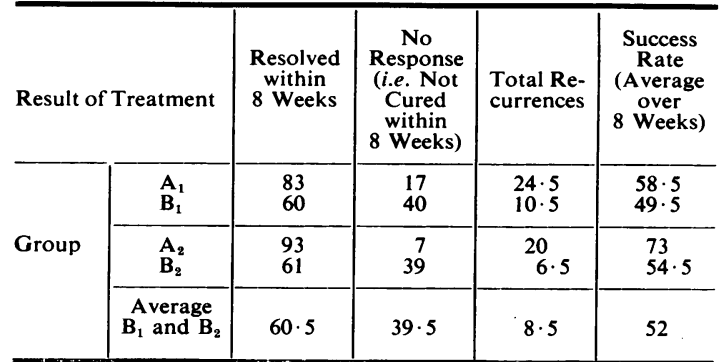

The reasons for recurrences are analysed in Table IX (opposite); alcohol is seen to be the predominant factor, closely followed by those in whom no history could be obtained. Sexual intercourse caused a recurrence in five out of 26 recurrences.

Chronic prostatitis was the commonest complication and a few patients developed cystitis, notably in the control groups (Table X, opposite). The incidence of complications was highest in the control groups and least in Group $A_{2}$. 
TABLE IX

CAUSE OF RECURRENCE

\begin{tabular}{|c|c|c|c|c|c|c|c|}
\hline Cause & . & .. & $\begin{array}{l}\text { Sexual } \\
\text { Inter- } \\
\text { course }\end{array}$ & Alcohol & $\begin{array}{c}\text { Muscular } \\
\text { Activity }\end{array}$ & $\begin{array}{c}\text { No } \\
\text { Reason }\end{array}$ & Total \\
\hline \multirow{2}{*}{ Group } & \multirow{2}{*}{$\cdots$} & $\begin{array}{l}A_{1} \\
A_{2}\end{array}$ & $\begin{array}{l}3 \\
1\end{array}$ & $\begin{array}{l}5 \\
3\end{array}$ & $\begin{array}{l}0 \\
0\end{array}$ & $\begin{array}{l}2 \\
5\end{array}$ & $\begin{array}{r}10 \\
9\end{array}$ \\
\hline & & $\begin{array}{l}\mathrm{B}_{1} \\
\mathrm{~B}_{2}\end{array}$ & $\begin{array}{l}0 \\
1\end{array}$ & $\begin{array}{l}1 \\
2\end{array}$ & $\begin{array}{l}1 \\
0\end{array}$ & $\begin{array}{l}2 \\
0\end{array}$ & $\begin{array}{l}4 \\
3\end{array}$ \\
\hline Totals & $\cdots$ & . & 5 & 11 & 1 & 9 & 26 \\
\hline \multicolumn{3}{|c|}{$\begin{array}{l}\text { Per cent. Total } \\
\text { Recurrence }\end{array}$} & 19 & 42 & 3 & 36 & 100 \\
\hline
\end{tabular}

TABLE X

COMPLICATIONS

\begin{tabular}{|c|c|c|c|c|c|c|}
\hline \multicolumn{2}{|c|}{ Complications } & $\begin{array}{l}\text { Chronic } \\
\text { Prostatitis }\end{array}$ & Cystitis & Total & $\begin{array}{l}\text { No. of } \\
\text { Patients } \\
\text { Followed- } \\
\text { up }\end{array}$ & $\begin{array}{l}\text { Per cent. } \\
\text { (All } \\
\text { Complica- } \\
\text { tions) }\end{array}$ \\
\hline \multirow{2}{*}{ Group } & $\begin{array}{l}A_{1} \\
A_{2}\end{array}$ & $\begin{array}{l}9 \\
6\end{array}$ & $\begin{array}{l}0 \\
0\end{array}$ & $\begin{array}{l}9 \\
6\end{array}$ & $\begin{array}{l}41 \\
45\end{array}$ & $\begin{array}{l}22 \\
13\end{array}$ \\
\hline & $\begin{array}{l}\mathbf{B}_{1} \\
\mathbf{B}_{2}\end{array}$ & $\begin{array}{r}8 \\
10\end{array}$ & $\begin{array}{l}3 \\
2\end{array}$ & $\begin{array}{l}11 \\
12\end{array}$ & $\begin{array}{l}38 \\
44\end{array}$ & $\begin{array}{l}29 \\
27\end{array}$ \\
\hline \multicolumn{2}{|l|}{ Totals } & 33 & 5 & 38 & & \\
\hline
\end{tabular}

No troublesome side-effects were noted, but the incidence of diarrhoea was greater in the treated groups (Table XI).

TABLE XI

SIDE-EFFECTS

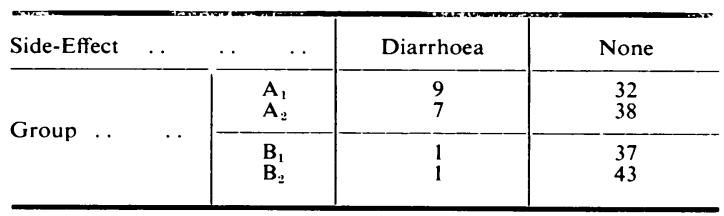

Finally, Table XII gives the bacteriological pattern of the urethra tefore treatment and that of the prostatic secretion after resolution of the urethritis. The staphylococcus was grown in most

TABLE XII

BACTERIOLOGY

\begin{tabular}{l|c|c|c|c|c}
\hline \multicolumn{1}{l|}{ Organism } &. & $\begin{array}{c}\text { Staphylo- } \\
\text { coccus }\end{array}$ & Proteus & Coliforms & $\begin{array}{c}\text { Trichomonas } \\
\text { vaginalis }\end{array}$ \\
\hline \multirow{4}{*}{ Urethral } & $\mathrm{A}_{1}$ & 41 & 1 & 3 & 1 \\
& $\mathrm{~A}_{2}$ & 46 & 1 & 4 & 2 \\
\hline & $\mathrm{B}_{2}$ & 41 & 1 & 4 & 0 \\
\hline \multirow{5}{*}{ Prostatic } & $\mathrm{B}_{2}$ & 50 & 1 & 3 & 0 \\
\hline & $\mathrm{A}_{1}$ & 33 & 1 & 3 & 0 \\
& $\mathrm{~A}_{2}$ & 25 & 3 & 3 & 0 \\
\hline & $\mathrm{B}_{1}$ & 22 & 3 & 5 & 0 \\
& $\mathrm{~B}_{2}$ & 32 & 0 & 9 & 0 \\
\hline
\end{tabular}

cases, as was to be expected, since it is part of the normal urethral flora.

\section{Discussion}

The information gathered was obviously not all relevant to this particular investigation of the effect of Sigmamycin on NGU, but it was felt that this trial would also prove a useful method of observing the natural course of the disease in the control series, and might indicate further possible fields of investigation. In addition, the method evolved for the investigation may be made the basis of a standard procedure for conducting future trials of new drugs.

From the results of the investigations, it would appear that NGU is a disease affecting young men, either married or single, who have usually had sexual intercourse with a regular contact, an average of 11 to 12 days before the onset of symptoms. It is quite common for a patient to have had a previous episode of urethritis, either gonococcal or nongonococcal.

The results of treatment show that a quick response to Sigmamycin is obtained in a significantly larger percentage if a large dose is used rather than a small dose. A further large percentage show gradual resolution over a period of up to 8 weeks, but the results in controls show that a similar percentage would have recovered without treatment in the same period. However, at the end of 8 weeks, the smallest percentage of patients still having urethritis is found in the group treated with the larger dose, and there are slightly fewer recurrences in this group. The success rate, taking an 8-week period and counting recurrences within this period as failures, was 73 per cent. using a large dose of Sigmamycin and $58 \cdot 5$ per cent. using a small dose (Table VIIID).

It is much more desirable from the patient's point of view, and also from that of minimizing the chance of spread of infection, to obtain a quick cure, and taking a 7-day period, the cure rate is 71 per cent. using a large dose and only 39 per cent. using a small dose (Table VIIIC). The first figure is close to that quoted by Mayne (1957), who found a 70 per cent. cure rate in treating the abacterial type of NGU with tetracycline. This, together with the low cure rate of 39 per cent. using a small dose, indicates that synergism between the two mixed antibiotics does not exist, and that the activity of Sigmamycin is presumably that of its most active constituent.

Of the non-treated controls, about $60 \cdot 5$ per cent. recover within 8 weeks, but some 8.5 per cent. are liable to have recurrences during that time. Thus, 
52 per cent. can te expected to recover uneventfully without treatment in 8 weeks; similarly Gartman and Leibovitz (1955) gave 58.5 per cent. as the expected spontaneous recovery rate in 8 weeks.

There appears to be slightly less likelihood of a recurrence or of complications if a larger dose of Sigmamycin is used rather than a small dose. Sideeffects are unimportant.

Oates (1958), treating two small groups of patients with Sigmamycin, used $2 \mathrm{~g}$. daily for 5 days for fifteen patients and half that dose for eighteen patients. The results showed Sigmamycin to be very effective in treating NGU. Very few failures were recorded for the second group and none at all for the first, but there were a few relapses in each group. Willcox (1957) also obtained good results with Sigmamycin in NGU and found that this drug compared very favourably with other antibiotics. Similar encouraging results have been found by Chiarenza (1957) who treated two small groups of patients with NGU and post-gonococcal urethritis.

\section{Summary and Conclusions}

An account is given of a standard procedure for investigating the effect of Sigmamycin on nongonococcal urethritis using the double-blind control method and two different dosage schedules.

The criterion used in assessing progress was the weekly two-glass test, using early morning specimens of urine which were qualitatively and quantitatively similar for a period of 8 weeks. Patients were re-treated at the end of this period or before if strictly necessary when no response was obtained.

Three categories of response were defined and a fourth category for recurrences. A large dose produced a quick response in 71 per cent. of cases with less likelihood of recurrence and complications. The controls showed that 52 per cent. may be expected to recover spontaneously in 8 weeks without treatment. A smaller dose produced an immediate response in only 39 per cent. and allowed 44 per cent. to resolve slowly (a percentage similar to that which would recover spontaneously if untreated).

The results seem to indicate a lack of synergism in Sigmamycin with regard to treating NGU and they seem to justify the use of a larger dose of $0.5 \mathrm{~g}$. 6-hrly for 5 days rather than a small dose of $0.1 \mathrm{~g}$. 6-hrly for 4 days.

I should like to thank Dr. C. S. Nicol for his encouragement during the trial and for his assistance in preparing this paper.

I am indebted to Messrs. Pfizer Ltd. for providing the Sigmamycin and I wish particularly to thank Dr. W. Williams, medical adviser to Pfizer Ltd., for his invaluable help.

I am also grateful for the patience and co-operation of Mr. Bird and the staff of Lydia Depar tment, St. Thomas's Hospital, over a period of nearly 2 years.

\section{REFERENCES}

Chiarenza. A. (1957). Minerva Med. (Torino), 48, 2692.

Gartman, E. and Leibovitz, A. (1955). Brit. J. vener. Dis., 31, 92.

Mayne, G. O. (1957). Ibid., 33, 244.

Oates, J. K. (1958). Ibid., 34, 38.

Willcox, R. R. (1957). Med. Press, 238, 562. 